Adjunktus

PTE ÁJK

\title{
A modern költségvetési jog kialakulása az európai jogi kultúrában
}

\section{The Development of Modern Budgetary Law in the European Legal Culture}

The states have to use public funds. It is a fundamental problem how can a state acquire money for fulfilling its obligations and tasks and how can it spend these funds properly. Basically two sides can be separated and scrutinized: the expenditures and the revenues. During the historical development the monarchs had fundamentally the power to make decisions in fiscal questions: they could prescribe taxes (contributions) and spend money without any restriction, public finances and the private wealth (expenditures) of the ruler weren't separated. Later the orders and the parliaments vindicated different rights to restrict the power of the monarchs: they could offer the taxes and since than the rulers couldn't impose taxes without their contributions. These very important restrictions appeared in different fundamental laws (for example in the Magna Charta Libertatum in England). It was very essential that the expenditures should be controlled as well. The next huge step according to that was the acquisition of the right to make detailed prescriptions on the field of expenses. In constitutional democracies many legal sources regulate the field of budgets in modern states: different principles and detailed provisions prescribe the requirements of acquisition and the spending of funds. The current financial decisions appear in the annual detailed budgets which are accepted and their execution are controlled by the parliament on the base of publicity and transparency. This paper scrutinizes the development of the legal frames of the budgets.

Keywords: budget, budgetary law, expenditures, revenues, taxation

\section{Bevezető gondolatok}

Egy korszerű államháztartás alappillére a költségvetés (a közbevételek és a közkiadások megfelelő tervezése és kezelése) a közfeladatok finanszírozása és teljesítése szempontjából alapvető jelentőségű kérdések. Minél több feladat teljesítését vállalja az állam, annál összetettebb jogi szabályozás megalkotása és végrehajtása szükséges.

Mióta állami funkciók léteznek, azóta szükséges valamilyen jellegű, szintû pénzügyi gazdálkodási tevékenység végzése, még akkor is, ha - Bónis György meghatározásával élve - adott esetben csak ,primitív államüzremröP' volt szó. ${ }^{1}$ Az államok eredetileg csak a klasszikus funkciókat (jogalkotás, rend- és honvédelem, közigazgatás, igazságszolgáltatás) látták el, azonban - alig kétszáz éve - a közfeladatként meghatározható funkciók körének kibővülése kezdődött meg: megjelentek a szociális-jóléti szolgáltatások (oktatás, egészségügy, szociális igazgatás), majd ezek is kiszélesedtek

\footnotetext{
${ }^{1}$ MEZEY, Magyar Alkotmánytörténet 41.
} 
további feladatokkal (például környezetvédelemmel), valamint - különösen az 1929-ben kezdődött gazdasági világválság nyomán - felmerült az igény, hogy az állam a gazdasági folyamatokba is beavatkozzon a gazdasági krízisek megelózése és a már kialakult válságok következményeinek kezelése érdekében. E feladatok körének bővülésével egyre összetettebb államháztartási szabályok megalkotása vált szükségessé, a demokratikus jogállamoknak pedig az egyik alapvető feladata, hogy biztosítsa a megfelelő jogi szabályozást a közpénzek minél hatékonyabb, átláthatóbb és felelősségteljesebb elköltése érdekében.

A tanulmány arra vállalkozik, hogy áttekintse az államháztartás, illetve ezen belül a költségvetési jog fejlődése szempontjából releváns európai mérföldköveket arra törekedve, hogy kiemelje e jogterület alakulásának releváns állomásait és fő kérdéseit. Nem feladata az egyes korszakok történelmi sajátosságainak részletes vizsgálata, sokkal inkább a fejlődés tendenciái képezik az elemzések tárgyát. E célkitűzés alapvetően három terület elemzésével valósítható meg: a bevételekről való döntési jogosultság, a kiadásokról való döntési jogosultság valamint magának a költségvetési döntések megjelenítése (hatásköri, eljárási kérdések) illetve azok végrehajtása és ellenőrzése.

\section{A költségvetés fogalma}

A költségvetés Navratil Ákos szerint „Azt a számszerü összeállitást, mely az állam, ill. köztestület

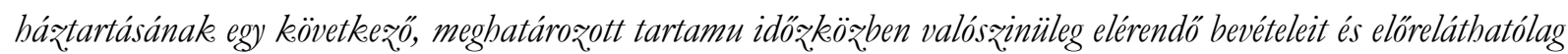
teljesitendö kiadásait rendszeresen feltünteti és ennyiben az állam vagy köztestület tervezett munkásságának is programmját adja, állami, községi stb. költségvetésnek mondjuk. A költségvetés szó helyett nálunk is használatos az idegen származásu budget szó (bouge, bougette, francia szó = börtáska)." Hozzátette fontos jellemzőként, hogy „Költségvetésröl valamely háztartásban csak fejlett gazdasági és közjogi viszonyok közö̈tt lehet szó. Pénzgazdaság kell hozzá. A naturálgazdaság a budget számszerüségét nem birná meg. Amint fejlett közjogi viszonyokat kiván, úgy egyúttal az alkotmányosságnak, a parlamentarizmusnak is legerösebb támasza. A költségvetés a kormányzat és igazgatás irányitásának és ellenörzésének esqköze a parlamentek kęében".

A költségvetések jogszabályi úton kerülnek elfogadásra és kihirdetésre. Az állami (központi) költségvetések esetében ez a jogszabályi típus rendszerint törvény. A magyar Alkotmánybíróság megállapította, hogy a költségvetési törvény kiemelt kezelését a sajátos jogi jellege, különleges alkotmányos szerepe, illetve a kiemelkedő gazdasági és politikai jelentősége indokolja. A költségvetés pedig nem más a tartalma szerint, mint az állam gazdálkodásának éves terve. A költségvetés címzettjei az állam szervei, amelyeket a törvény felhatalmaz arra, hogy a költségvetésben számukra biztosított előirányzatot az egyéb jogszabályok figyelembevételével felhasználják kötelezettségeik teljesítésére vagy más, jogilag megengedett célokra. A költségvetési törvény csak az elfogadásának módját tekintve törvény, tartalma szerint viszont inkább egyedi pénzügyi döntések sorozata. ${ }^{3}$

A költségvetés biztosítja a feladatok ellátásához szükséges kiadások, valamint e kiadások fedezetéül szolgáló bevételek tervezésének és teljesítésének egy adott időszakra vonatkozó

\footnotetext{
2 NAVRATIL, A társadalmi gazdaságtan és a közháztartástan vázlata 244.

3 4/2006. (II. 15.) AB határozat
} 
számszerű (pénzben pontosan rögzített) kereteit. A bevételek megszerzésének szabályai már a költségvetésen kívül esnek: külön jogszabályok rendezik a bevételek típusait - így elsődlegesen a különböző közterheket, illetve adósságot keletkeztető ügyleteket -, másrészt pedig azok megszerzését, kezelését, kikényszerítését. Ugyancsak kívül esnek a közpénzek felhasználásának jogi szabályai a költségvetés keretein: ezeket rendszerint az államháztartási, támogatási, illetve közbeszerzési jogszabályok rendezik. A megfelelő garanciális előírások kialakítása tehát kulcskérdés; ezek érvényesülése azért különösen fontos, mert ezek hiányában „, k költségvetés csak egy darab papir, kivéve, ha léteznek garanciák, amelyek lebetôvé teszile a költségvetés hatályosulását. A költségvetéskészités három rész̧böl tevödike össze: a tervezet megszövegezéséböl, a felhatalmazásból vagy elfogadásból, a végrehajtásból vagy a költségvetési kontrollbóp'. ${ }^{4}$

A költségvetések alapvetően két oldalból épülnek fel: a bevételi és a kiadási oldalból. Jogtörténeti vizsgálatkor a bevételi oldalhoz kapcsolódó jogi és politikai kérdések merültek fel először, ennek megfelelően ezen terület fejlődésének alapvető kérdéseit célszerű első lépésként elemezni. A középkori Európában a húbéri viszonyokon alapuló gazdaságok, társadalmak szerveződtek. Az ilyen államokban általában három fejlődési szakaszt szokás elkülöníteni: a patrimoniális, a rendi valamint az abszolút monarchiák korszakát. Elsőként tehát ezen korszakok államháztartási jellemzői vizsgálandók.

\section{A költségvetési döntések bevételi oldalának fejlődése}

A patrimoniális uralom időszakában az uralkodó és az állam vagyona nem különült el egymástól. Az uralkodó döntéseit, magatartását nem korlátozta tőle független szerv vagy testület, a bevételek és kiadások - azaz a költségvetés kiadási és bevételi oldalának - meghatározása tekintetében korlátok nem léteztek. ${ }^{5}$ A patrimoniális uralom időszakában nem volt külön államháztartás, az uralkodó magánháztartása volt lényegében az államháztartás, amely az uralkodó birtokainak bevételein alapult (az ún. domaniális jövedelmek kiemelkedő jelentőséggel bírtak). A bevételek sorsáról (a kiadásokról) az uralkodó döntött, az uralkodói hatalom különleges természetéból folyó bevételek száma még csekély volt, és jelentőségük sem volt túl nagy. A birtokokból befolyó bevétel mellett tipikus jövedelemforrás volt például a regálé. ${ }^{6} \mathrm{Az}$ államháztartás kialakulásának kezdete a rendi dualizmus korszakához köthető. Az uralkodói birtokból befolyó jövedelmek még jelentősek voltak, azonban egyre inkább emelkedett más bevételi formák jelentősége is (pl. regálék, királyi haszonvételek, illetékek). A korszak további sajátossága volt, hogy a kiadások elkezdték elveszíteni magánjogi jellegüket, az adók kivetése terén pedig a rendek különböző jogosítványokat szereztek. Az abszolút monarchia idôszakában a rendek beleszólási jogának a korlátozása és a tisztán az uralkodó akaratától függő államháztartás megalapozása volt az elsődleges uralkodói célkitűzés. ${ }^{7} \mathrm{Az}$ abszolút állam egyik fontos jellemzője, hogy a központosító államhatalom az adóztatással

\footnotetext{
4 VANDEGRIFT, Budgets and Budgetary Control 55.

${ }^{5}$ Ld. SCHulze, Pénzügyi-jog.

${ }^{6}$ A regálé a királynak fenntartott jogosítványból származó bevétel, illetve haszonvétel, így például vadászati jogokból, bányászatból, vámszedésből, pénzverésből származó bevételek sorolhatóak ide. Ld. FÖLDES, Az államháztartástan (pénzügytan) 125., HeLler, Pénzügytan 95-133.

${ }^{7}$ Heller, Pénzügytan 19.
} 
megteremtette az állandó hadsereg és a kiterjedt közigazgatás alapjait, valamint hogy célul tűzték ki a modernizációt. A centralizáció mellett a régi rendi hatalmi elit már nem, az új elit, a polgárság pedig még nem volt képes befolyást gyakorolni az államhatalomra. ${ }^{8} \mathrm{~A}$ modern államok (a polgári alkotmányosság) csak később, eltérő időben és módon, sajátos államtípusokat kialakítva (liberális jogállam, nemzetállam stb.) jelenik meg különleges alapelvek, követelmények érvényesülése mellett (parlamentarizmus, államhatalmi ágak szétválasztása, állam és egyház szétválasztása, jogegyenlőség stb). ${ }^{9}$

Az egyes korszakokhoz kapcsolódóan két alapvető jogi, illetve közgazdasági kérdést kell megvizsgálni: az egyik a fedezeti elvek kérdése, a másik pedig az adómegajánlás, mint a korlátok nélküli uralkodói döntéshozatalt korlátozó jogintézmény.

A fedezeti elvek azt jelölik, hogy az állam milyen jogcímeken tud bevételhez jutni. Ezek lehetnek magánjogiak (például kölcsön, bérbeadás, közvagyon értékesítése); ilyenkor az állam úgy viselkedik, mint egy magánjogi ügyletben egy fél (nem rendelkezik különleges hatalmi helyzettel). Lehetnek közjogi típusú bevételek: ebben az esetben az állam már a közhatalmával élve egyoldalúan állapít meg kötelezéseket bizonyos alanyi körre nézve (például adók, illetékek, járulékok kivetésével). És végül megemlíthetőek a vegyes típusú fedezeti elvek, amelyek esetében a magánjogi és a közjogi elemek vegyülnek (például koncessziókból eredő bevételek). ${ }^{10}$

Az egyes történelmi korszakokban a különböző fedezeti elvek más-más arányban voltak jelen. A patrimoniális uralom időszakában a magánjogi fedezeti elvek voltak dominánsak, hiszen a kiterjed uralkodói birtokrendszer jövedelmei jelentették a kincstár fő bevételeit. Az idő előre haladásával azonban az uralkodói birtokokból származó bevételek háttérbe szorultak, miután az uralkodói vagyon az adományozások folytán csökkent. Ennek ellenére nem tűnt el teljesen, azonban jelentősége csekély lett, miután az adóelv vált a természetes fedezeti elvvé. Megemlítendő azonban, hogy voltak olyan országok még a 20. században is, amelyekben jelentős fedezeti elvként működött: Poroszországban 1914 előtt az összbevétel 50\%-a, Finnországban és Svédországban 1927 és 1928 között pedig a költségvetési bevételek egyötöde az állam magángazdasági bevételeiből származott. ${ }^{11}$

A fedezeti elvek közül az adóelv csak a későbbi fejlődési korszakban vált egyeduralkodóvá. Eleinte az adókat inkább rendkívüli bevételi forrásokként alkalmazták, a domaniális (a királyi birtokrendszeren nyugvó) államháztartásban az illetékek, vámok, regálék voltak a jellemzők, de még a királyi birtokok elzálogosítása is alkalmazható eszköznek bizonyult. Csak akkor kezdett felértékelődni az adóztatás, amikor a korábbi megoldások már nem bizonyultak elégségesnek. Ezt a fejlődési utat bejárta Anglia, Franciaország, a német tartományok és Magyarország is, bár ez az átmenet eltérő módon és időben valósult meg. Magyarországon később ment mindez végbe: először Habsburg Albert kért rendkívüli segélyt hadi célokra 1439-ben (bár adótermészetű közbevételek már Szent István kora óta léteztek). Ezzel szemben Angliában már a 12. században megjelent az adó általános jellemzőjével rendelkező vagyonadó, a 13. században pedig az adóviselési kötelezettség elvét elismerik a parlament adómegajánlási jogával kapcsolatban. Magyarországon a

\footnotetext{
${ }^{8}$ KAJTÁR - HERGER: Egyetemes állam- és jogtörténet 75.

${ }^{9}$ KAJTÁR - HERGER: Egyetemes állam- és jogtörténet 133-160.

${ }^{10}$ Heller, Pénzügytan 95.

${ }^{11}$ HeLLER, Pénzügytan 101
} 
regálészerű bevételek (például pénzverési haszon) csak lassan kezdtek el adójelleget ölteni. Ennek ellenére ezeket is csak a rendek beleegyezésével lehetett emelni. ${ }^{12}$ Elötérbe került tehát az adóelv, és egyoldalúan, a bevételi viszonylatban igyekeztek a közjogi elemeket kiterjeszteni. A rendi parlamentarizmus kifejlődésével azonban mind a bevételi, mind pedig a kiadási oldalon érvényre kívánták juttatni a közjogi elemet: a magánjogi bevételek csak maradványszinten maradnak meg, az adóelv győzedelmeskedett, a bevételi és a kiadási oldal közüggyé vált. A rendi parlamentarizmus pénzügyi rendszere minden vonatkozásban közjogi jellegü, a népakarat következményeként kerül meghatározásra. ${ }^{13}$

A másik fontos kérdés tehát az említett adómegajánlási jog kialakulása és gyakorlása. E jogot abból szokás levezetni, hogy az adózás eredendően önkéntes hozzájárulás volt - erre utalnak az adóra az egyes idegen nyelvekben használt kifejezések (így például a latin subsidium vagy az angol aid) -, és ez az önkéntes szolgáltatás csak fokozatosan vált kényszerszolgáltatássá. A középkorban szerepe volt az önkéntességeknek - azaz az adómegajánlás (contributio) jogának - a húbérurak és az államfő közötti kapcsolatban, azonban a jobbágyokat terhelő adók esetében semmiféle önkéntesség nem mutatható ki, ahogy a kényszerjelleg az adók elnevezéséből is megállapítható (például a latin taxa, decima vagy az angol duty). ${ }^{14}$

Angliában 1215-ben a Magna Charta Libertatumban már szerepelt a renddé szerveződő társadalmi csoportok adómegajánlási joga, de teljes körű elismerését és kifejezését az 1689. évi Bill of Rights tartalmazta, amikor az új uralkodópár (Orániai Vilmos és Stuart Mária) és a parlament közötti hatáskörmegosztást szabályozta. ${ }^{15}$ A Magna Charta Libertatum 12. cikkelye elốrta, hogy általános nemesi hozzájárulás nélkül nem lehet hozzájárulást (adót - angol szóval „aid”) valamint pajzspénzt („scutage”) megállapítani, kivéve például, ha mindez váltságdíj megfizetése érdekében történik. A szöveg által említett „scutage” (scutagium) egy olyan pénzbeli hozzájárulás (adóként is viselkedő közteher) volt, amellyel a bárók személyes katonai szolgálatukat válthatták meg. Ez azon alapult, hogy a húbéri jogviszonyban a vazallus szolgálni tartozott urát (a hủbér nagyságához igazodó haderôvel és felszereltséggel hadba kellett vonulnia hűbérura oldalán), azonban e szolgálatot pénzösszeg megfizetésével megválthatta. A király ezt rendszeres adóvá tette lényegében (egyre gyakrabban szedette be), 1214. május 26-án pedig utasítást adott, hogy olyan mértékben szedjék be, amely példa nélküli volt. Az északi bárók, akik később részt vettek a Magna Charta aláírásának kikényszerítésében, megtagadták mind a katonai szolgálatot, mind pedig a scutage fizetését arra hivatkozással, hogy nem tartoznak tengerentúli szolgálattal. A Magna Charta létrejöttének az egyik vezető oka a scutage volt, de nem a mértéke, hanem inkább annak gyakorisága. I. János manipulatív módon és bárók ellenőrzésére használta fel a feudális adóztatást (ha előírta olyanoknak is adó megfizetését, akik nem tudtak fizetni, akkor e tartozást a politikai fegyelem megszilárdítására használhatta fel). Ezen kívül további adóemelések és intézkedések is születtek. E fejlemények érthető módon nyugtalanították a bárókat, így felkelés szervezésébe fogtak. Nemcsak a bárók, hanem az egyház is szenvedett a magas adótehertől, így a papság - és

\footnotetext{
12 NAVRATIL, A társadalmi gazdaságtan és a közháztartástan vázlata 271. Lásd még JUSZTINGER: Adótörténeti szemelvények a régi magyar jogból 50-58.

${ }^{13}$ HeLleR, Pénzügytan 19.

${ }^{14}$ MeZnerics, Pénzügyi jog a szocialista gazdálkodásban és a nemzetközi kapcsolatokban 252-253.

15 NAVRATIL, A társadalmi gazdaságtan és a közháztartástan vázlata 249.
} 
mellettük több társadalmi csoport - is támogatta a bárók törekvéseit. A bárók bevonultak Londonba, és arra kényszerítették a királyt, hogy Runnymede mezején írja alá 1215. június 15-én a Magna Chartát, amelyre úgy tekintenek, mint az első olyan dokumentumra, amely korlátozza az uralkodói hatalmat, és amely egy fontos lépés volt a jog uralmának, azaz a jogállamnak a megteremtése útján. Valójában már korábban, 1100-ban I. Henrik is írt alá olyan dokumentumot, amely az adóztatási hatalom korlátozását tartalmazta (Charter of Liberties, vagy más néven Coronation Charter). A Magna Charta csak egy fontos kezdeti lépés volt egy hosszú vitában, illetve harcban, amelyet a nemesség és az uralkodó egymással folytatott évszázadokon át. ${ }^{16}$ A korabeli angol viszonyokra egyébként az volt jellemző, hogy a hadba vonulásra kötelezettek inkább fizették a pajzspénzt, minthogy személyesen teljesítsék a fegyveres szolgálatot, viszont voltak olyan csoportok, amelyeknek különös nehézséget okozott a fizetési kötelezettség teljesítése. ${ }^{17}$

Az angol történelemben a bevételi döntések kérdése egyébként az észak-amerikai gyarmatokon is kulcskérdésnek számított: a gyarmatok a 18. században követelték, hogy beleszólhassanak az őket érintő adóztatási kérdésekbe, azonban az angol kormányzattal folytatott hosszas küzdelmek nem hozták el számukra a kívánt eredményt. A „nincs adózás képviselet nélkül” („No taxation without representation”) elvből adódó sorozatos konfliktusok végül a gyarmatok függetlenségének deklarálásához vezetett 1776-ban, létrehozva ezzel az Amerikai Egyesült Államokat. ${ }^{18}$

Franciaországban az általános rendi gyúlést, az états généreaux-t is megillette az adómegajánlás joga, az abszolutizmus korszakában azonban nem gyakorolhatták, viszont 1795-ben a directorium alkotmánya elismerte. Magyarországon I. Mátyás (1458 - 1490) uralkodása idején, 1471-ben fogalmazták meg, hogy ne szedjen a király semminemü rovást az ország lakosaitól azok akarata nélkül. ${ }^{19}$ A mohácsi vész korában keletkezett Érdi Kódex jellemzően mondta az adóról, hogy az a ,jobbagyt nagy ostor adowal gyettry". ${ }^{20}$ A határozott időre szóló adómegajánlás egyébként közjogi vita tárgyát képezte a 19. századi Magyarországon: a reformkorban voltak olyan álláspontok, amelyek szerint az adótörvényeknek nem határozott időre kell szólniuk, hanem addig, amíg a hatályukat meg nem szüntetik. Ezzel biztosítható, hogy a közkiadások ne maradjanak fedezetlenül, még akkor sem, ha az Országgyúlést nem hívják össze vagy nem sikerül az uralkodónak és az Országgyülésnek megegyeznie. Deák Ferenc azonban az adómegajánlás jogát az alkotmányosság szempontjából kulcsfontosságúnak tartotta, kiemelve, hogy a felhatalmazás csak határozott időre szólhat. Felszólalásában megfogalmazta, hogy „A mi jus publicumunk czáfolbatatlan axiomája s az. országnak tagadhatatlan jussa szerint a magyar adófizetó csak annyi adót fizethet, mennyit a diaeta felajánlott, s csak addig firethet, a meddig felajánlotta, és minden fillér, melyet az ajánlott summán felïl, s minden nap, melyen a kiszabott idön túl fizet, törvénytelen. [...] Ha már az állana, hogy Magyarországon az adó soba meg nem szünhetik, akekor természetesen következnék, hogy ha a nemzet és fejedelem között az adó iránt valamely országgyülésen a tractatus meg nem készülne, s a diaeta a nélkül oszlanéke el, akekor az elöbbi adó tovább folyna s

\footnotetext{
${ }^{16}$ CoCKFIELD - MAYLES, The Influence of Historical Tax Law Developments on Anglo-American Laws and Politics 43-49.

${ }^{17}$ BÁRÁNY, Az „elkorcsosult feudalizmus” fogalma, megítélése és hagyománya az angol történetírásban 65 .

18 Ld. COCKFIELD - MAYLES, The Influence of Historical Tax Law Developments on Anglo-American Laws and Politics 58-62.

${ }^{19}$ NAVRATIL, A társadalmi gazdaságtan és a közháztartástan vázlata 249.

${ }^{20}$ MEZNERICS, Pénzügyi jog a szocialista gazdálkodásban és a nemzetközi kapcsolatokban 252-253.
} 
a magyar adózó oly adót fizetne, melyet az, országgyúlése meg nem ajánlott, oly idöre fizetné, melyre ajánlva nem vala". ${ }^{21}$

A költségvetési jog fejlődése szempontjából kiemelkedő jelentőségű elvi dokumentum a francia Nemzetgyúlés által 1789-ben elfogadott Emberi és Polgári Jogok Nyilatkozata, amelynek XIII. és XIV. cikke a következő követelményt fogalmazta meg: „XIII. A karhatalom és a körigazgatás költségeinek fedezésére nélkülözhetetlenül szülkséges mindenkinek közös hozzájárulása; s e hozzájárulást, kinekkinek képessége szerint, a polgárok összessége közt egyenlöen kell elosztani. XIV. A polgároknak saját személyükeben vagy képviselök útján joguk van e közös hozzájárulás szü̈kségszerüségét megállapitani s azt szabadon megszavazni, valamint felhasználását nyomon követni, s meghatározni mennyiségét, alapját, elosztását, behajtását és idôtartamát’ ${ }^{22}$ E rendelkezésekből egyértelmúen megállapítható az arra vonatkozó igény, hogy a polgárok (a társadalom tagjai) legyenek a kiindulópontjai a bevételek és kiadások meghatározásának, választott képviselők útján ők határozzák meg a költségvetésre (a bevételekre és kiadásokra) vonatkozó döntéseket, és ne pedig uralkodói önkény.

Megvalósult tehát az anciene regime pénzügyi rendszerének átalakítása, a kiváltságok (adómentességek) megszüntetése. Az adó kifejezés (impôt) helyett ezért alkalmazták inkább a hozzájárulás (rate) szót, mivel az jobban kifejezésre juttatta azt az elvet, hogy a közterheket egyenlő arányban szétosztják, és e felosztás a terheket viselők hozzájárulásán alapult. Ezt a hozzájárulást pedig a képviselőik útján tették meg, a törvényhozást illette meg az adók megszavazásának joga, a költségvetési szabályok megalkotása nem függött többé a király jóváhagyásától. A monarchia titkos pénzügyei helyébe - amelyben bármilyen visszaélés elképzelhető volt - a közpénzügyek nyilvánossága és megvitathatósága lépett. ${ }^{23}$

A modern, jogállami pénzügyi jogban a nullum tributum sine lege elv érvényesülése folytán a népképviseleti elven nyugvó törvényhozás hatáskörébe tartozik a kötelező jellegű befizetések előírása, és ezáltal a költségvetés alapvető forrásait jelentő adók meghatározása. E garanciális jelentőségú alapelv érvényre jutása biztosítja, hogy az adókat ne a végrehajtó hatalom írhassa elő saját belátása (önkénye) szerint, így az adók határozott időre történő megajánlása szükségtelenné vált (azok a vonatkozó törvények módosításáig, illetve hatályon kívül helyezéséig fizetendőek), bár nem kizárt, hogy valamely jogrendszer az évenkénti szavazást az adókra nézve előírja. ${ }^{24}$

\section{A kiadási oldal szabályozásának fejlődése}

A költségvetés másik oldalát a kiadások megállapítása jelenti: a megszerzett bevételek elköltésének jogi kérdései is rendkívüli jelentőségúek, hiszen ha a megajánlott bevételeket nem a megszavazott (engedélyezett) célra költi a jogosult (az uralkodó, a kormány), hanem a társadalom szempontjából hasznossággal nem járó javakat és szolgáltatásokat vásárol belőle (például mértéktelen fényưzés fenntartására fordítja az uralkodó), akkor a befizetések - az adófizetői áldozatvállalások -

\footnotetext{
${ }^{21}$ KÓNYI, Deák Ferencz beszédei http://mek.oszk.hu/02200/02213/html/

22 http://mek.oszk.hu/00000/00056/html/228.htm

${ }^{23}$ BRISSAUD, A History of French Public Law 567.

${ }^{24}$ Lásd többek között a belga alkotmány (1831. február 7.) 171. cikkét. http://www.verfassungen.eu/b/belgien31index.htm
} 
hiábavalónak bizonyulnak. Éppen ezért kulcsfontosságú az a kérdés, hogy az uralkodóval szemben álló csoportok milyen jogosítványokat képesek megszerezni a kiadási oldalt illetően.

Az angol történelemben is a Parlament és az uralkodó közötti küzdelemként írató le az a folyamat, amelynek során a törvényhozás végül megszerezte a költségvetési döntések feletti jogot. A 18. századtól kezdve a törvényhozás arra törekedett, hogy mind az adók és egyéb bevételek (például kölcsönfelvételek engedélyezése) eldöntésének joga ne a király (a kormányzat), hanem a Parlament jogkörébe kerüljön, viszont a bevételek megszavazásának joga még nem jelentette azt, hogy a kiadások feletti kontrollt is érvényesithették, a tényleges jogi és egyéb feltételeket később alakították ki ehhez kapcsolódóan. 1911-től a népképviseleti elven választott Képviselőház hozhat csak pénzügyi döntéseket, a Lordok Háza ilyen kérdésekben nem dönthet. ${ }^{25}$ Megjegyzendő, hogy az említett változást megalapozó 1911-es brit törvény ${ }^{26}$ külön rendelkezik a pénzügyi tárgyú törvényjavaslatokhoz (Money Bill) kapcsolódó jogalkotási hatáskörökről, lépésekről. Elsőként meghatározta a tárgykörök nevesítésével, hogy mit is sorol ebbe a körbe (azaz mi minősül Money Bill-nek). Így például ide tartozik az adók, közterhek kivetése, visszavonása, csökkentése, módosítása, szabályozása, kölcsönfelvétel. A törvény kifejezetten említi, hogy nem tartoznak a helyi közpénzügyek a hatálya alá ('́gy a helyi hatóságokat, szervezeteket megillető bevételek, kölcsönök). ${ }^{27}$ A törvény első cikkének első bekezdése értelmében „Ha egy Képviselóház által elfogadott és legalább az. ülés befejezése elött egy hónappal felterjesztett törvényjavaslatot a Lordok. Háza módositás nélkül nem fogadja el egy bónapon belül az̧ követöen, hogy hozzá felterjesztették, a Képviselöház eltérö rendelkezése hiányában a törvényjavaslatot be kell mutatni Öfelségének és a kinyilvánitott hozzájárulása alapján a Parlament által elfogadott törvénnyé válik annak ellenére is, ha a Lordok Háza ąt nem támogatta”. Ez azt jelenti, hogy egy hónappal halaszthatja el a Lordok Háza az ilyen tárgyú törvényjavaslatok elfogadását.

Ahhoz, hogy a kiadási oldal feletti tényleges kontroll érvényesülhessen, feltétlenül szükség van arra, hogy a kiadásokat is megfelelő módon megtervezzék, a kiadási előirányzatokat kellő módon részletezzék, hiszen ennek hiányában hiába hagyják jóvá a kiadási tételeket, ha azok megfogalmazása nélkülözi a konkrétumokat. Ilyen esetben ugyanis a kiadások teljesítése terén túlságosan nagy mozgástér illeti meg az előirányzat feletti rendelkezést gyakorló személyt (az uralkodót), amely mozgástér akár akkora is lehet, hogy teljesen kiüresíti a jóváhagyás tartalmát. ${ }^{28}$

A részletezés ezen említett gyakorlata Angliában II. Károly (1660 - 1685) uralkodása idején vette kezdetét abból a megfontolásból, hogy a Németalföld ellen viselt háborúra megszavazott költségeket ténylegesen az ehhez kapcsolódó kiadásokra fordítsák, és ne pedig az udvar költekezéseit finanszírozzák belőlük. Túl általános előirányzat-meghatározás esetében ugyanis a parlament képtelen kontrollálni a kormányt. Viszont az sem célszerű, ha túlságosan kis összegú,

\footnotetext{
25 BunBury, Control of Public Expenditure in Great Britain 726.

${ }^{26}$ An Act to make provision with respect to the powers of the House of Lords in relation to those of the House of Commons, and to limit the duration of Parliament, 1911 [1\&2 Geo. 5. Ch. 13.] Ld. még BradLEY - EwING, Constitutional and Administrative Law 207-215., illetve a Jackson v Attorney General, UKHL 56, [2005] 4 All ER 1253. számú esetet.

${ }^{27}$ Az önkormányzatokról, illetve az adóztatás lehetőségérôl lásd COPUS - ROBERTS - WALL, Local Government in England. Centralisation, Autonomy and Control 158-159.

${ }^{28}$ FÖLDES, Az államháztartástan (pénzügytan) 59-61.
} 
minden részletre kiterjedő kiadási tételeket foglalnak a költségvetésbe, hiszen ilyen esetben a kormány tényleges szükséges és indokolt pénzügyi mozgástere szűnne meg. ${ }^{29}$

Ahogyan arról a bevételek körében szó volt, az 1789-ben elfogadott Emberi és Polgári Jogok Nyilatkozatának XIV. cikke a közteherviseléshez hozzákapcsolta a kiadások meghatározását, valamint a végrehajtáshoz kapcsolódó kontroll jogosultságát is. Ez azért volt különösen fontos lépés, mert a 18. századi Franciaországban sem volt közügy a pénzügy és a költségvetés kérdése. Az abszolút monarchiák időszakában a költségvetéssel kapcsolatos adatok, döntések nem voltak nyilvánosak, sőt Franciaországban egy időben jogszabályi úton kifejezetten tiltották a költségvetési adatok közlését, nyomtatását, terjesztését, azt a király és minisztereinek magánügyévé tették. Richelieu bíboros nézete szerint egyenesen el kellett rejteni a profán szemek elól, mivel hogy a pénzügyi-költségvetési döntések képezik az államok idegeit. Mindebből az is következett, hogy egy 1764. március 28-ai rendelet megtiltotta minden olyan mú nyomtatását, árusítását, amely a közpénzügyek kezelésére vonatkozott. ${ }^{30}$ (Az állam idegeinek tekintette a költségvetési-pénzügyi döntéseket egyébként a 16. században Jean Bodin is.) $)^{31}$

\section{A modern költségvetési jogok kialakulása a 19. században és a magyar polgári modernizáció}

A költségvetési jog fejlődésének szempontjából kulcskérdés volt, hogy a parlamentarizmus kiteljesedésével milyen jogi garanciák biztosíthatóak a költségvetések tervezése, elfogadása, végrehajtása és ellenőrzése szempontjából. A 18. század utolsó évtizedeiben megjelentek az első írott alkotmányok (Egyesült Államok, 1787; Franciaország, 1791), amelyeket a következő évszázadban újabbak követtek.

Az újszülött belga királyság 1831. február 7-én elfogadott alkotmányában rögzített szabályok modellértékű mérföldkőnek tekinthetők. Ezen alkotmány többek között az 1791. évi francia alkotmányon és az 1815. évi holland alaptörvényen alapult; az előbbiből egy sor rendelkezést átvett a közpénzügyek rendszerére vonatkozó szabályok körében is. ${ }^{32} \mathrm{~A}$ belga alkotmány alaptételként rögzítette a parlament költségvetési jogát, amely a későbbi alkotmányok legnagyobb részébe is bekerült.. ${ }^{33}$ A hatályos szöveg ${ }^{34}$ egyébként az V. részben (a 170-181. szakaszokban) foglalkozik a közpénzügyekkel, és többek között rendelkezik a nullum tributum sine lege elvről (az adót törvény állapíthatja meg), illetve az állam által felhatalmazott szervezetek adóztatási lehetőségéről, továbbá tartalmazza azt az előírást is, amely szerint az adókról évenként kell szavazni, és megújitás hiányában csak egy évig hatályos a bevezető jogszabály. A költségvetés elfogadásának jogát a Képviselók Házának jogkörébe utalja az alkotmány, emellett rendelkezik arról is, hogy a vallon, a flamand és a német közösség pénzügyi rendszerét külön törvények szabályozzák. Külön alapelvként rögzítik a költségvetések és az elszámolások (zárszámadások) közzétételének

\footnotetext{
${ }^{29}$ FÖLDES, Az államháztartástan (pénzügytan) 59-61.

${ }^{30}$ Leroy-Beaulieu, Pénzügytan 12.

31 Heller, Pénzügytan 27.

32 BOCKEN - DE BONDT, Introduction to Belgian Law 50-51.

${ }^{3}$ NAVRATIL, A társadalmi gazdaságtan és a közháztartástan vázlata 249.

34 http://www.verfassungen.eu/b/belgien94-index.htm
} 
követelményét. A közpénzügyi szabályok tárgyalása a Számvevőszékre vonatkozó előírások megfogalmazásával zárul.

A következőkben röviden áttekintésre kerül a magyar költségvetési jog fejlődése. Az 1848. év a pénzügyi jog fejlődése szempontjából is jelentős volt Magyarországon. Az 1848. évi VIII. törvénycikk rendelkezett a közös teherviselésről: „Magyarország s a kapcsolt részek minden lakosai, minden közterheket különbség nélkül egyenlöen és aránylagosan viselike”. A független magyar felelős ministerium alakításáról szóló 1848. évi III. törvénycikk 37. \-a megfogalmazta a költségvetéskészítési és a zárszámadási kötelezettséget: „A ministerium az ország jövedelmeinek és szüleségeinek kimutatását - s a multra nézve az általa kezelt jövedelmekröli számadását országgyülési megviæsgálás, s illetóleg jóváhagyás végett - évenként az alsó táblánál bemutatni köteles". ${ }^{35}$ Az országgyülés évenkénti üléseiről szóló 1848. évi IV. törvénycikk 6. \-a garanciális jelleggel fogalmazta meg, hogy „Az évi ülés az utolsó évróli sqámadásnak, és következó évi költségvetésnek a ministerium által leendô elöterjesztése, $s$ az irántoki határozatnak meghozatala elött be nem rekesztethetnek, sem az országgyülés fel nem oszlathatike”.

Az 1848/49-es szabadságharc leverését követően, az osztrák jog uralmának időszakában önálló magyar költségvetési jog sem létezett, az ún. magyar költségvetés - amely szerves részét képezte az osztrák birodalmi költségvetésnek - Bécsben készült. Az alkotmány rögzítette, hogy a költségvetést és az adókat törvénybe kell foglalni, azonban a császárt is feljogosította törvényi szintű jogforrás kibocsátásának jogával, amellyel lényegében korlátok nélkül élhetett. Ezeket a jogi normákat a császár helyett a valóságban a Minisztertanács alkotta meg, és pátens alakjában a császár nevében adták ki. Az 1850 és 1867 közötti pénzügyi jogalkotás rendkívül aktív volt, számtalan különböző szintű jogforrás jelent meg. ${ }^{36}$

Az osztrák-magyar közjogi kiegyezés eredményeként, magyar részről az 1867. évi XII. törvénycikkel létrejött az Osztrák-Magyar Monarchia mint egy speciális reálunió a magyar és az osztrák fél között. A kiegyezési törvénycikk kijelölte a közös ügyeket: a külügyet, a hadügyet és a meghatározottak fedezésére vonatkozó pénzügyet (16-17. §): „A pénæügyet annyiban ismeri a magyar országgyülés kö̈ösnek, a mennyiben közösek lesznek azon költségek, melyek a fenebbiekben közöseknek elismert tárgyakra forditandók. Ez azonban ngy értelmez̧endö: hogy az emlitett tárgyakra megkivántató összues költségek. közösen határoztassanak meg. [...] Magyarország minden egyéb államköltségét, a magyar felelós ministerium elöterjesztésére, az országgyülés alkotmányos uton fogja elhatározni; azokat, mint átalában minden adót, a magyar ministerium, minden idegen befolyás teljes kizárásával, saját felelössége alatt veti ki, szedi be és kezzeli." A törvénycikk meghatározta a közösügyi bizottságok (delegációk) megalakítását, múködését és az alkufolyamatot (azaz a hozzájárulás arányáról való megegyezést).

Az I. világháborút követően önállóvá vált Magyarországon elsődleges kérdés volt az államháztartás rendezése. Az ehhez szükséges kölcsön a Népszövetség közreműködésével valósult meg, azonban cserébe Magyarország lemondott a pénzügyi szuverenitásáról (1924. évi IV. törvénycikk), hiszen népszövetségi főbiztos (Jeremiah Smith) ellenőrizte a bevételeket és a kiadásokat, a pénzeszközök felhasználását (meg is vétózhatott kiadásokat), a zálogként lekötött állami bevételek pedig zárolt számlákra érkeztek, és e számlák feletti rendelkezéshez a fóbiztos hozzájárulására volt szükség. ${ }^{37}$

\footnotetext{
35 A törvénycikkről lásd MATLEKOVITS, Magyarország államháztartásának története 1-6.

${ }^{36}$ KISS - SZITA, A pénzügyi jogalkotás és jogforrási rendszer főbb vonásai a feudalizmustól a felszabadulásig 150.

37 KovÁCs, Pénzügyi ellenőrzés változó erőtérben 94. 73. lábjegyzet.
} 
A II. világháború utáni időszakban az állami pénzügyekről szóló 1979. évi II. törvény (Ápt.) emelhető ki, amely célul tűzte ki az állami pénzügyek rendszerének, irányításának, múködésének és ellenőrzésének alapvető szabályozását. Egy ilyen jellegű törvény, mint az ún. államháztartási törvény, régi vágya volt a pénzügyi jog tudománya művelőinek, azonban az 1980-as évek végére már nem feltétlenül volt korszerűnek tekinthető, mivel fontossá vált a monetáris és a fiskális politika megfelelő elhatárolása, valamint az, hogy a költségvetés és a bankok pénzügyei önállósuljanak. ${ }^{38} \mathrm{Az}$ Ápt. szabályozta az állami költségvetés céljait, bevételeit és kiadásait, a kapcsolódó eljárási szabályokat, a tanácsok költségvetését, a nemzetközi pénzügyeket, a bankrendszert, a vállalati pénzügyi rendszert, az ellenőrzést és a számvitelt.

Az Országgyűlés hatalma 1948-at követően erőteljesen korlátozott volt, gyakorlatilag elveszítette jogalkotói funkcióját. A szovjetblokk országaiban általánosan érvényesülő közjogi felfogásnak megfelelően az Alkotmány ugyanis a következő jogkört biztosította a kollektív államfői testület, a Népköztársaság Elnöki Tanácsa (NET) számára: „Ha az Orsqággyülés nem ülésęik, az, Országgyülés jogkörét az. Elnöki Tanács gyakorolja; az, alkotmányt azonban nem változtathatja meg". ${ }^{39} \mathrm{Az}$ alkotmányi felhatalmazásnak megfelelően a NET törvényerejú rendeleteket alkothatott, és mivel az Országgyưlés évente átlagosan csak 8,5 napot ülésezett, ezért a törvényalkotási tevékenysége nem volt jelentős, évente csak néhány törvény került elfogadásra. Az 1982-es év abból a szempontból kiemelkedő, hogy mindössze két törvényt fogadtak el: az egyik a zárszámadási, a másik pedig a költségvetési törvény volt. ${ }^{40} \mathrm{Az}$ Ápt. meghatározta az állami költségvetés fogalmát is: a definíció szerint az állami költségvetés a központi költségvetést és a tanácsok költségvetését foglalta magában, ugyanakkor a rendszerébe beletartoztak az elkülönített állami pénzalapok is. Fontos jellemző volt, hogy a független költségvetési (államháztartási) ellenőrzés rendszere sem múködhetett, miután 1949-ben megszüntették az Állami Számvevőszéket és csak a rendszerváltás idôszakában, 1989-ben döntöttek az újbóli felállításáról.

A rendszerváltást követően szükségessé vált az államháztartás rendbetétele (is), így alapvető jelentőségű kérdés volt a megfelelő pénzügyi jogi szabályozás kialakítása. Az államháztartás komplex jogi szabályozását az államháztartásról szóló 1992. évi XXXVIII. törvény (régi Áht.) elfogadásával alkotta meg az Országgyúlés. Ezt megelőzően átmeneti szabályokat alkottak a költségvetésről, az államháztartás viteléről. Ilyen törvény volt a Magyar Köztársaság 1991. évi állami költségvetéséről és az államháztartás vitelének 1991. évi szabályairól szóló 1990. évi CIV. törvény, amely a preambulumában rögzítette, hogy az Országgyúlés az államháztartási rendszer újraszabályozását megelőzően, a közpénzekkel való hatékony és ellenőrizhető gazdálkodás igényével az 1991. évi állami költségvetésről és annak végrehajtásához kapcsolódóan az államháztartás vitelének egyes átmeneti szabályairól szól. Ugyancsak átmeneti államháztartási szabályokat rögzített a 1991. évi XLVII. törvény a költségvetés mellett. Megjegyzendő, hogy e törvény az 1992-es év legnagyobb feladataira is kitért bevezetőjében: „az 1992. évi gazdaságpolitika középpontjában a gazdaság strukturális átalakitása, az infláció mérséklése, valamint - a piacgazdaság épitésével együttjáró - foglalkoztatási és szociális gondok enybitése áll. A hosszabb távra szóló gazdasági növekedés megalapozása érdekében fokozatosan mérsékelni kell a költségvetésen keresztüli jövedelemátcsoportositást úgy, hogy

\footnotetext{
${ }^{38}$ SZENTIVÁNYI, Bankjog 123-124.

39 A Magyar Népköztársaság Alkotmányáról szóló 1949. évi XX. törvény 30. \(5) bekezdés.

40 MEZEY, Magyar Alkotmánytörténet 406-407.
} 
közben a kiadások belsö arányai is módosuljanak az alapvetö társadalmi és gazdasági követelményekhez. igazodóan". Ilyen előzmények alapján került megalkotásra a régi Áht., amely már egységes jelleggel, az államháztartási alapelvekre hivatkozással kívánta az államháztartást átfogó jelleggel szabályozni.

A közpénzügyi rendszer teljes reformja valósult meg 2011-ben: a korábbi alkotmányt új Alaptörvény váltotta fel, amely már külön közpénzügyi fejezetet is tartalmaz. Külön törvényeket fogadott el az Országgyúlés a gazdasági stabilitásról és a nemzeti vagyonról (több más jelentős törvény mellett is). Az alapvető célkitűzés a stabil, fenntartható költségvetési és pénzügyi gazdálkodás, továbbá az államadósság elleni küzdelem jogi alapjainak (feltételeinek) megteremtése volt.

A központi költségvetésre vonatkozó szabályozás mellett a helyi önkormányzatok pénzügyeinek fejlődését is szükséges röviden áttekinteni. A dualizmus korában a köztörvényhatóságok rendezéséről szóló 1870. évi XLII. törvénycikk 2. 『-a deklarálta, hogy „Önkormányzati jogánál fogva a törvényhatóság saját belïgyeiben önállólag intézkedik”, ennek keretében pedig rögzítette „ą önkormányzat és közigazgatás költségeit megállapitja, s a fedezetröl gondoskodik”. A törvényhatóságok (azaz a vármegyék, szabad királyi és más városok stb.) határozatban ${ }^{41}$ rendelkeztek a költségvetésükről. A törvénycikk ezt olyan, a közgyúlés hatáskörébe tartozó feladatként definiálta, amely csak miniszteri jóváhagyás után volt végrehajtható (a törvénycikk emellett rendelkezett részletszabályokról is); a Buda-Pest fővárosi törvényhatóság alakitásáról és rendezéséről szóló 1872. évi XXXVI. törvénycikk is hasonló szabályokat tartalmazott. Ugyancsak tartalmazott költségvetésekre vonatkozó előírásokat a községek rendezéséről szóló 1871. évi XVIII. törvénycikk. A közigazgatás rendezéséről szóló 1929. évi XXX. törvénycikk a törvényhatósági bizottság közgyűlésének jogkörébe utalta a saját gazdasági természetű ügyek irányítását, valamint a költségvetés és zárszámadás elfogadását. A II. világháborút követően az első tanácstörvény (1950. évi I. törvény) a tanács kizárólagos határozathozatali jogkörébe sorolta a helyi gazdasági terv, illetve a költségvetés megtárgyalását és elfogadását (az összeállitás a végrehajtóbizottság feladata volt). A második tanácstörvény (1954. évi X. törvény) deklarálta, hogy a tanács vezeti - egyebek mellett - a helyi gazdasági tevékenységet, ennek keretében pedig a hatáskörébe tartozott az állami népgazdasági terv és az állami költségvetés keretein belül a költségvetés megállapítása, továbbá irányította és ellenőrizte a terv és a költségvetés végrehajtását, megvitatta az ezzel kapcsolatos beszámolókat. Az utolsó tanácstörvény (1971. évi I. törvény) úgy rendelkezett a pénzügyi terv és a költségvetés elfogadásáról, mint át nem ruházható tanácsi hatáskörről; ezen kívül említést tett a költségvetési beszámolóról is. A rendszerváltást megelőzően az Ápt. is szabályozta a tanácsok költségvetését, továbbá általános jelleggel rögzítette, hogy az állami költségvetés a központi költségvetést és a tanácsok költségvetését foglalja magában. A rendszerváltás időszakában új alapokra kellett helyezni a helyi közigazgatást: az önkormányzati rendszer kiépítése lehetőséget kínált a helyi közügyek ténylegesen demokratikus intézésére. Az autonómia azonban csak a pénzügyi autonómia ${ }^{42}$ biztosításával juthat érvényre, ennek megfelelően került sor például a helyi adókra vonatkozó törvény megalkotására az önkormányzati törvény mellett. A 2011-es reform az önkormányzatok gazdálkodását is alapjaiban érintette, hiszen új önkormányzati törvény (2011. évi

\footnotetext{
${ }^{41}$ A hatályos jogszabályok szerint jogszabályban, rendeletben fogadják el az önkormányzatok a költségvetéseiket.

${ }^{42}$ Lásd az Alkotmánybíróság 41/2005. (X. 27.) számú határozatát, Kiss László különvéleményét.
} 
CLXXXIX. törvény) került elfogadásra; átalakították az önkormányzatoknak nyújtható támogatások rendszerét is az ún. feladatfinanszírozás bevezetésével (a támogatásokat úgy kell megállapítani, hogy az önkormányzatok bevételi érdekeltségét fenntartsák), emellett feladatalapú támogatás is nyújtható, továbbá egyéb támogatásokat is biztosíthat a törvényhozás.

\section{6. Összegző megállapítások}

A költségvetési jogra vonatkozó szabályozás fejlődése egyes országokban különböző módon alakult: eltérő történelmi események, gazdasági környezet, hagyományok és politikai rendszerek következtében különböző utat jártak be az egyes államok. A tanulmány arra vállalkozott, hogy a fejlődés főbb közös elemeit, jellemzőit, tendenciáit, eredményeit mutassa be példákkal alátámasztva.

A költségvetési jog kialakulása lényegében nem más, mint pénzügyi konfliktusok eredője és azok története. A polgári modernizáció kora előtt, a patrimoniális uralom időszakában, a rendi illetve az abszolút államokban, az államtípus függvényében eltérő pénzügyi politikát látunk. Ebben az időszakban költségvetési jogról beszélni még túlzás lenne. A patrimoniális monarchiákban az uralkodó akarata érvényesült, azt más kötelező erôvel bíró tényezők nem befolyásolhatták, az uralkodó és az állam vagyona egymástól nem különült el, az alapvető bevételi források a birtokokból befolyó (domaniális) jövedelmek voltak, de az adóztatás is alkalmazott megoldás volt. A királyi birtokrendszer jelentős részének eladományozása miatt kibontakozó rendi monarchiákban a megerősödő rendek már korlátozni kívánják az uralkodói döntéseket - adott esetben az önkényt -, és jogi garanciákat követelnek maguknak a bevételi oldalt illetően, amelynek nyomán elismerést nyert az adómegajánlási jog. Az abszolút monarchiákban a parlamentek, illetve rendi gyúlések jelentôsége visszaszorul, az uralkodók és kormányaik magánügyévé válnak, kiváltva ezzel az újabb konfliktusokat. Az átgondolatlan pénzügyi döntések sorozata állami krízisekhez, forradalmakhoz vezethetett, ́́gy a 18. század végétől kulcskérdéssé vált a költségvetések alkotmányos garanciáinak megteremtése, a törvényhozó testületek jogainak deklarálása, a végrehajtó hatalom jogosítványainak korlátozása, a hatékony ellenőrzés és elszámoltathatóság megteremtése, a felelős közpénzfelhasználás biztosítékainak érvényesítése. Fontos azonban, hogy a végrehajtó hatalom sem lehet eszköztelen, hiszen az ő feladata a költségvetések végrehajtása, amely feladatot csak akkor tudja ellátni, ha a kellő rugalmasság biztosított.

A megfelelő jogi szabályozás kialakítása azért különösen indokolt, mert az államok feladata egyre inkább bővül, újabb és újabb feladatok ellátását vállalja fel. Már nemcsak különböző közfeladatokat, közszolgáltatásokat kell finanszírozniuk, hanem a gazdasági folyamatokba is beavatkoznak a válsághelyzetek kezelése érdekében. A finanszírozó költségvetésektől eljutottak az országok a beavatkozó költségvetésekig, amikor is már nemcsak a bevételek és a kiadások megfelelő megtervezése és végrehajtása a lényeges, hanem azoknak a gazdaságra és a társadalomra gyakorolt hatása is. Mindez azonban a hagyományos költségvetési jog keretein kívül esik, hiszen ezek már általános, gazdaság- és társadalompolitikai kérdéseknek tekinthetőek. 


\section{Felhasznált irodalom}

BÁRÁNY Attila: Az „elkorcsosult feudalizmus” fogalma, megítélése és hagyománya az angol történetírásban. In: BESSENYEI József - FÜGEDI Márta - Ö. KOVÁCs József - RINGER Árpád, SCHIMERT Péter (szerk.): Történelmi Tanulmányok. Miskolci 1999

BOCKEN, Hubert - DE BONDT, Walter (szerk.): Introduction to Belgian Law. Brüsszel 2001

BradLEY, Anthony Wilfred - EwING, Keith D.: Constitutional and Administrative Law. Harlow, 2007

BRISSAUD, Jean: A History of French Public Law. Washington D.C. 2001

Bunbury, Henry: Control of Public Expenditure in Great Britain. Taxes - The Magazine, 1948. August.

COCKFIELD, Arthur J. - MAYLES, Jonah: The Influence of Historical Tax Law Developments on Anglo-American Laws and Politics. Columbia Journal of Tax Lax 2013/1. sz. 40-68.

Copus, Colin - RoBerts, Mark - WALL, Rachel: Local Government in England. Centralisation, Autonomy and Control. London 2017

FÖLDES Béla: Az államháztartástan (pénzügytan). Budapest 1912

HeLler Farkas: Pénzügytan. Budapest 1943

JUSZTINGER János: Adótörténeti szemelvények a régi magyar jogból. Jura 2018/1. sz. 50-58.

KAjTÁr István - Herger Csabáné: Egyetemes állam- és jogtörténet. Budapest - Pécs 2013

KISS Lászlóné - SZITA János: A pénzügyi jogalkotás és jogforrási rendszer főbb vonásai a feudalizmustól a felszabadulásig. Dolgozatok az állam- és jogtudományok köréből XVIII. Pécs 1987

KovÁcs Árpád: Pénzügyi ellenőrzés változó erőtérben. Budapest 2003

KÓNYI Manó: Deák Ferencz beszédei, I. (1829 - 1847) http://mek.oszk.hu/02200/02213/html/ (letöltve: 2018.12. 01.)

Leroy-Beaulieu, Paul: Pénzügytan. Budapest 1880

MATLEKOVITS Sándor: Magyarország államháztartásának története: 1867 - 1893. Budapest 1894

MEZEY Barna (szerk.): Magyar Alkotmánytörténet. Budapest 2002

MEZnERICs Iván: Pénzügyi jog a szocialista gazdálkodásban és a nemzetközi kapcsolatokban. Budapest 1972

NAVRATIL Ákos: A társadalmi gazdaságtan és a közháztartástan vázlata. Budapest 1908

SCHulze, Hermann: Pénzügyi-jog. Jogtudományi Közlöny 1878/39-45. sz. 313., 322., 332., 348. 262.

SZENTIVÁNYI Iván: Bankjog. Budapest 1988

VANDEGRIFT, Rolland A.: Budgets and Budgetary Control. Tax Magazine 1934/2. sz. 55-90. 